\title{
New directions in cervical cancer prophylaxis worldwide and in Poland - Case study of the Polish rural female population
}

\author{
Agnieszka Maździarz', Jerzy Wyględowski', Beata Osuch', Beata Jagielska², \\ Beata Śpiewankiewicz' \\ ${ }^{1}$ Department of Gynaecologic Oncology, Maria Sklodowska-Curie Memorial Cancer Centre and Institute of Oncology, \\ Warsaw, Poland \\ ${ }^{2}$ Department of Oncology and Internal Medicine, Maria Sklodowska-Curie Memorial Cancer Centre and Institute of \\ Oncology, Warsaw, Poland
}

Maździarz A, Wyględowski J, Osuch B, Jagielska B, Śpiewankiewicz B. New directions in cervical cancer prophylaxis worldwide and in Poland - Case study of the Polish rural female population. Ann Agric Environ Med. 2017; 24(4): 592-595. doi: 10.5604/12321966.1232093

\begin{abstract}
Introduction. Cervical cancer is one of the most frequent malignant neoplasms in females. Such neoplasms can be almost completely eliminated by means of adequate primary and secondary prophylaxis. The most developed countries focus their attention on the improvement of prophylaxis systems, test quality, and efficacy improvement, as well as on the expansion of the primary prophylaxis. In Poland, the discussions focus on the improvement of the malfunctioning population programme. Objective. Drawing on recent research findings, the article presents current Polish and global recommendations with regard to screening tests for cervical cancer. The results of the Population Programme of Prophylaxis and Early Detection of Cervical Cancer are discussed in the context of current trends of healthy behaviour among women inhabiting rural areas. Description of the state of knowledge. In the future, it will be relevant to increase the number of human papillary virus (HPV) tests as part of the prophylaxis programme, especially among the high risk patient group. In particular, there is a necessity to increase the number of vaccinations among young women, especially before the beginning of their sexual activity, as well as to establish new strategies of secondary prophylaxis in this group. At present, women who had been vaccinated should undergo routine screening.

In Poland, the report based on SIMP registry (IT System of Prophylaxis Monitoring), shows that only $27 \%$ of the 3.3 million of invited women participated in the cytology tests. The data analysis shows that women living in rural areas more often respond and participate in the tests, compared to women living in the cities (39.3\% vs. $16.8 \%)$.
\end{abstract}

Key words

cervical cancer, prophylaxis, screening of cervical cancer, cytology

\section{INTRODUCTION}

Cervical cancer is one of the most frequent malignant neoplasms in women. Such tumours can be almost completely eliminated by means of adequate primary and secondary prophylaxis. The value of the cytology in the diagnosis of cervical cancer was appreciated by Papanicolaou and Traut in 1941, who published an article in the American Journal of Obstetrics and Gynecology entitled 'The diagnostic value of vaginal smears in carcinoma of the uterus' [1]. The first screening tests were performed in the 1960s as part of the diagnostics of cervical cancer. Subsequent decades saw great improvements in the tests that have made them very efficient in fighting this type of cancer. The tests are still based on cytology, but they are performed with the increasing presence of molecular testing.

\footnotetext{
Address for correspondence: Agnieszka Maździarz, Department of Gynaecologic Oncology, The Maria Sklodowska-Curie Memorial Cancer Centre and Institute of Oncology, Warsaw, Poland E-mail: agaem855@interia.pl

Received: 19 March 2014; accepted: 25 June 2014; first published on February 2017
}

\section{OBJECTIVE}

This article presents the current recommendations regarding the population of women vaccinated against HPV, in light of the most recent literature on the subject. We also discuss new suggestions regarding the use of cytology tests and the tests used to detect the infection of the oncogenic type of the human papillary virus (HPV). The results of the program of prophylactic tests in Poland are presented in the context of healthy behaviour trends in rural women.

Description of the state of knowledge. The latest global recommendations regarding cervical cancer prophylaxis are based on current knowledge regarding the course of the human papilloma virus infection and cervical cancer carcinogenesis [2]. The US Preventive Services Task Force (USPSTF), American Cancer Society, American Society for Colposcopy and Cervical Pathology, and American Society for Clinical Pathology (ACS/ASCCP/ASCP), recommend starting the screening tests at the age of 21 , independently of sexual activity $[3,4]$. 


\section{MATERIALS AND METHOD}

For the presented study, the female population was divided into 3 groups, based on 3 different approaches to the treatment. Women aged 21-29 should undergo only cytology examinations every 3 years. The HPV tests are not recommended in this group because frequent, transient human papillary virus infections is the cause of the transient cytologic abnormalities. Solely active infection of the oncogenic types of the virus can increase the risk of intraepithelial neoplasia of the cervix of a high grade (CIN $3)$, as well as the risk of invasive cancer $[3,4]$.

Within the population of women aged $30-65$, ACS/ASCCP/ ASCP prefers the method of cytology- and virology-based co-testing performed every 5 years. It is acceptable to perform solely cytology tests every 3 years when there is no HPV tested [4]. USPSTF claims that both tests performed separately have a very similar diagnostic value, and recommends combined cytology and HPV tests only to the women who prefer longer intervals between screening tests [3].

There is no clarity and agreement regarding the choice of the virology test to be implemented as a common screening test $[4,5]$.

Women above the age of 65 who have had 2 normal test results within last 10 years, if one of these tests was performed within the last 5 years, and who were not treated in the past due to the intraepithelial neoplasia of the cervix of medium and high degree, do not require subsequent prophylactic tests, independently of their sexual activity. Women after hysterectomy, with no changes of the CIN 2 and CIN 3 type detected in the past, may also stop participating in the screening tests [4]. The ACS/ASCCP/ASC experts believe that women vaccinated against HPV should undergo routine screening.

Actual results indicate the high efficacy of the vaccines in the prevention of the changes related to human papilloma virus types 16 and 18 . It should, however, be remembered that $30 \%$ of the cervical cancer cases develop with the co-presence of other types of cancer. It should also be noted that there is no data regarding the length of immunity. In the future, it might turn out that these women will not require so frequent prophylactic tests, but at present, the very small number of vaccinated women and the extremely short follow-up time do not allow the drawing of appropriate conclusions, and the introduction of changes in the screening protocol $[2,6]$.

Specialists stress that $10 \%$ of cases of cervical cancer are diagnosed among women not participating in any screening programme, or among those who had their last test performed more than 5 years ago. In order to remedy this situation, multi-channel education, awareness campaigns, programmes promoting attachment to the screening, and an increase in the availability of the tests are recommended.

Aactivities performed in order to decrease the mortality due to cervical cancer should incorporate new strategies in screening and the treatment of the diagnosed abnormalities. In the future, it will be important to increase the presence of HPV tests as part of the prophylactic tests, especially in the high risk groups of patients $[4,5]$.

The USPSTF and ACS/ASCCP/ASCP experts agree that frequent prophylactic tests for cervical cancer do not offer any benefits, and might be actually harmful, causing short-term psychological stress, vaginal bleeding, infections, as well as negative impact on pregnancies. Therefore, annual 'cytology' should no longer be recommended because the risks are higher than the benefits. Too many false positive results lead to 'overtreatment', the multiplication of unnecessary procedures, and an increase in the risks for the women participating in them [2].

There is a need to increase the number of vaccinations among younger women, especially before the onset of sexual activity, as well as the need to develop the new strategies of secondary prophylaxis in this group. Subsequent observations and research in the population of older women should help to find the right age for discontinuing the screening tests, especially among HPV-negative women $[3,4]$.

The key question of cervical cancer prophylaxis in the future will be the detection of the HPV infection with the $\geq$ CIN II progression potential and its differentiation from the transient infections. Currently, the US Food and Drug Administration (FDA) recommends the tests based on Hybrid Capture 2 technology, as well as PCR. Many randomized, controlled studies showed 90-95\% clinical sensitivity in the detection of $\geq$ CIN II changes [7].

In contrast to the cytologic test, HPV test results are very objective and reproducible, which minimalizes the differences in the results among different laboratories. The authors of the presented study posit that the increase in the sensitivity of HPV tests will result in a significant increase in false positive results: positive hrHPV without $\geq$ CIN II. This, in turn, will generate unnecessary procedures and costs. Therefore, it is important to balance the sensitivity and specificity in the detection of the human papilloma virus infection. The differences in the clinical specificity of HPV tests are mainly caused by the possibility of the detection of the transient infections, which have low titer. The transient infections are not a factor leading to the oncogenesis. Their detection is potentially harmful for screening tests because it generates, among women with positive results, unnecessary observations, anxiety and increases costs [8]. In the future, molecular tests will become more precise in the recognition of pre-neoplastic conditions. Currently, the producers make great efforts to promote widely the new HPV tests, stressing their strong sensitivity. These exceptional diagnostic possibilities might be of limited diagnostic value for the population tests, but they will become valuable diagnostic tool in single cases. Observation indicates that not all the CIN 2 changes undergo progression and, in fact, are not real pre-neoplastic states. A new generation of tests differentiate these changes based on the expression of E6/E7 oncoproteins with HPV genotyping.

The Population Programme of Prophylaxis and Early Detection of Cervical Cancer was developed and implemented in Poland in 2006, and is still active [9, 10, 11]. The report of the Ministry of Health concerning the realization of the National Programme of Neoplastic Disease Treatment of 30 May 2011, based on the SIMP registry (IT System of Monitoring and Prophylaxis), shows that only $27 \%$ of the 3.3 million of invited women participated in the cytologic tests. Among 75,854 patients with abnormal results, only $9,567(12.6 \%)$ were qualified to the next stage of the expanded diagnostics. The fate of the remaining $87.4 \%$ is unknown. Among women, who underwent expanded diagnostics, 111 cases of invasive cervical cancer were detected, as well as 13 cases of glandular cancer of the cervix $[9,10]$. Currently, every year in Poland, more than 1,800 women die as a result of this neoplasm; this is one of the highest mortality indicators 
in Europe [9, 12]. Following the publication of the results, the discussion continues regarding the main problems and barriers in the execution of the effective prophylaxis. The reasons for the screening failure are:

- low awareness of women regarding the necessity of prophylactic tests;

- an unsatisfactory number of women responding to invitations;

- lack of adequate monitoring and registry of cytology tests already performed, and tests also performed outside the population programme.

Analysis of the participation of inhabitants of cities and rural areas was performed based on the data from the SIMP system. The results show that women from rural areas more often respond and participate in the tests than the women in the cities (39.3\% vs. 16.8\%). In the Silesian Province, all rural women responded to the invitations and the attendance was above $100 \%$ since some women participated in the tests more than once in 3 years [13]. This is surprising, taking into the consideration that the results based on the questionnaires and declarations of the respondents indicate significantly higher participation in prophylactic tests of the women from urban than from rural areas. It is probable that the women from cities more often use private healthcare consults, not registered by the SIMP system. On the other hand, it should be remembered that for the inhabitants of the rural areas it is more difficult to access a physician's surgery, which is also located at a quite distance. They inhabit the regions with a poorly developed infrastructure, and which also frequently have a lower level of socioeconomic development. Direct contact with the inhabitants of the rural areas and the facilitation of the tests should meet with a positive reaction. It seems that the involvement of nurses and midwives in the support and performance of the screening test would produce even better results in these regions.

As far as the whole country is concerned, the risk of death related to neoplasms for women is higher in the cities than in the rural areas (by ca. 10\%) [14]. The strong differentiating factor of the level of mortality is education. This corresponds with the prophylactic tests. The cytology is more frequently performed by women with secondary and higher education (20\%) than women with basic and professional education (6\%) [13]. It is interesting that the performed studies show no difference between the level of knowledge regarding HPV infection among girls in cities and in the rural areas [15].

The Polish Coalition for the Fight against Cervical Cancer has estimated that with the prophylactic tests reportability of about $60 \%$, the cervical cancer mortality will decrease by half during the next 10 years [10]. Unfortunately, the delayed diagnostics of the neoplasms, high costs of treatment, problematic results, and above all, an increased number of premature female deaths, constitute important reasons for intensifying the mortality limiting activities. The following changes to the programme are proposed:

- education regarding prophylaxis, starting at the level of the secondary school,

- adjustment of the education programme to the intellectual level of the target female group, and in a way in which they will think about their health and its protection, while keeping in mind that the main source of information for many women, especially those living in the rural areas, by television;
- an increased role of midwives and primary care physicians, especially in accessing elderly women and those who are poor, professionally inactive, and living in rural areas;

- introduction of mobile forms of cytology exams - cytobuses (as in the case in breast cancer prophylaxis),

- implementation of primary prophylaxis by the development of the population HPV vaccination programme;

- implementation of the evidence system of tests performed outside the programme, and follow-up of women with abnormal test results;

- monitoring of the quality of the tests performed $[10,12$, $15,16,17]$.

\section{CONCLUSIONS}

Prophylaxis within our medical care has been marginalized for many years. Most of our society is characterized by the lack of healthy behaviour patterns, low awareness of health issues, and lack of motivation in women. The crucial activity for the future will be to increase the sense of self-responsibility for one's own health.

The most developed countries owe the success they have achieved in the fight against the cervical cancer to well-functioning screening programmes. Currently, these countries focus their attention on improvements in the prophylactic systems, improvement of the quality and efficacy of the tests, as well as expansion of the primary prophylaxis (vaccination). In Poland, discussions regarding cervical cancer prophylaxis focus on the malfunctioning population programme. Analysis of this problem and the search for solutions go beyond the scope of medicine, and focus on the organization of society.

\section{REFERENCES}

1. Hajdu SI, Ehya H. A Note from History: Foundation of Diagnostic Cytology. Annals of Clinical \& Labolatory Science 2008; 38: 296-299.

2. Kizer N, Peipert JF. Cervical Cancer Screening: Primum Non Nocere. Ann Intern Med. 2012, 156: 896-897.

3. Moyer VA. U.S. Preventive Services Task Force. Screening for Cervical Cancer: U.S. Preventive Services Task Force Recommendation Statement. Ann Intern Med. 2012, 156: 880-91.

4. Slaslow DS, Solomon D, Lawson HW, Killackey M, Kulasingam SL, Cain J, et al. American Cancer Society, American Society for Colposcopy and Cervical Pathology, and American Society for Clinical Pathology Screening Guidelines for the Prevention and Early Detection of Cervical Cancer. Am J Clin Pathol. 2012, 137: 516-542.

5. Castle PE, Rausa A, Walls T, Gravitt PE, Partridge EE, Olivo V, et al. Comparative community outreach to increase cervical cancer screening in the Mississippi Delta. Prev Med. 2012, 52: 452-455.

6. Centers for Disease Control and Prevention (CDC). National and state vaccination coverage among adolescents aged 13 through 17 years - United States 2010. MMWR Morb Mortal Wkly Rep. 2011; 60(33): 1117-23.

7. Anhang R, Goodman A, Goldie SJ. HPV Communication: Review of Existing Research and Recommendations for Patient Education. CA: A Cancer Journal for Clinicians 2004; 54(5): 248-259.

8. Meijer CJLM, Berkhof J, Castle PE, et al. Guidelines for human papillomavirus DNA test requirements for primary cervical cancer screening in women 30 years and older, Snijders PJF. Int J Cancer 2009; 124 (3): 516-520.

9. Spaczyński M, Karowicz-Bilińska A, Nowak-Markwitz E, et al. Raport Centralnego Ośrodka Koordynującego: Podsumowanie realizacji populacyjnego programu profilaktyki i wykrywania raka szyjki macicy w ramach narodowego programu zwalczania chorób nowotworowych lata 2007-2010. Poznań 2010. 
10. Rekomendacje kompleksowych zmian w obszarze profilaktyki raka szyjki macicy w Polsce: Polska Koalicja na Rzecz Walki z Rakiem Szyjki Macicy. http://koalicjarsm.pl/rekomendacje.html (access: 01.12.2013)

11. Ministerstwo Zdrowia Departament Polityki Lekowej i Farmacji. Informacja Ministerstwa Zdrowia na temat leczenia chorób onkologicznych. 05.01.2011. www.mz.gov.pl/wwwfiles/ma_struktura/ .../ komunikat_pl_05012011 (access: 01.12.2013)

12. Wojciechowska U, Didkowska J, Zatoński W. Nowotwory złośliwe w Polsce w 2010 roku. Centrum Onkologii - Instytut im. M. SkłodowskiejCurie, Warszawa 2012.

13. Spaczyński M, Karowicz-Bilińska A, Rokita W, Molińska-Glura M, Januszek-Michalecka L, Seroczyński P, Uchlik J, Nowak-Markwitz E. Attendance rate in the Polish Cervical Cancer Screening Program in the years 2007-2009. Gin Pol. 2010; 81: 655-663.
14. Wojtyniak B. Wybrane problemy zdrowotne. Umieralność kobiet 15-49 lat. In: Raport „Zdrowie kobiet w wieku prokreacyjnym 15-49 lat. Polska 2006.” Program Narodów Zjednoczonych ds. Rozwoju. Warszawa 2007; 32-33.

15. Sawaryn D, Wróbel A. Poziom wiedzy młodych dziewcząt na temat raka szyjki macicy. Medycyna Rodzinna 2011; 2: 35-42.

16. Chybicka A, Jackowska T, Dobrzańska A, Godycki-Ćwirko M, et al. Zalecenia grupy ekspertów dotyczące pierwotnej profilaktyki raka szyjki macicy u dziewcząt i młodych kobiet. Pediatria Polska 2010; 85(4): 359-369.

17. Adamska-Wełnicka A. Rak szyjki macicy - jak rozwiązać problem?. Służba Zdrowia. 2011; 43 (50): 4044-4051. 